Л. Ю. Малюга

кандидат юридичних наук, старший науковий співробітник юридичного факультету Київського національного університету імені Тараса Шевченка

\title{
СОЦІАЛЬНЕ ЗАБЕЗПЕЧЕННЯ НАСЕЛЕННЯ У ФРАНЦІї: ЗМІСТ ТА ШЛЯХИ ВДОСКОНАЛЕННЯ СОЦІАЛЬНОГО ЗАКОНОДАВСТВА УКРАЇНИ
}

Україна спирається на досвід більш досвідчених країн Європи із самого моменту проголошення незалежності. У 2014 році Україна остаточно обрала шлях європейського розвитку й задекларувала початок демократичних реформ та перетворень у всіх сферах суспільного життя, кінцевою метою яких є підвищення життєвих стандартів населення України, а також входження до складу Європейського Союзу. Оскільки низку вітчизняних інституцій треба розробляти фактично з нуля, у цьому контексті цілком доцільно спиратись на досвід більш розвинених держав, а Франція є вдалим прикладом для цього, оскільки вона є високорозвиненою країною, яка характеризується високими соціальними стандартами, довгою історією законотворення, а також реальною реалізацією законодавчих приписів на практиці. Соціальне забезпечення населення цієї держави є набагато досконалішим та вищим, аніж в Україні, а отже, здійснення відповідного наукового дослідження $\mathrm{\epsilon}$ доцільним та необхідним.

Актуальність дослідження питання специфіки соціального законодавства Франції та шляхів удосконалення соціального законодавства України на основі цього досвіду полягає у тому, що соціальне забезпечення у цій державі здійснюється на високому рівні. Україна, як і Франція, є соціальною та правовою державою, тобто такою, у якій забезпечується соціальна безпека громадян й створюються необхідні і достатні умови для реалізації соціальних прав людини та громадянина, а також така, у якій встановлено верховенство права, про що свідчить стаття 1 Конституції України [5]. Paзом із тим Франція є такою соціальною та правовою державою по факту, а Україна більшою мірою лише декларує такі цілі. Більше того, французька система соціального захисту вважається однією 3 найдосконаліших систем в Європі та світі, адже вона задовольняє такі основні потреби, як захист від безробіття, охорону здоров'я, забезпечення у старості та захист сім'ї. Як свідчать статистичні дані, Франція посідає друге місце серед європейських країн за обсягами витрат державного бюджету на соціальну сферу, причому витрати становлять $30 \%$ бюджету [24, с. 104]. Для того щоб бути сучасною європейською державою та членом європейської спільноти, в Україні мають забезпечуватись права людини та здійснюватися їх захист, цінність людського життя і здоров'я має першочергово забезпечуватися державою, соціально-економічні потреби мають забезпечуватись у тих розмірах та обсягах, щоб задовольняти потреби населення. В Україні такі цілі декларуються у вищезгадуваній статті 1 Конституції України [5], а також у статтях 46,47 та 48 цього ж нормативно-правового акта. Згідно з положеннями Основного Закону, Україна є соціальною державою, як і будь-яка розвинена європейська країна, до співпраці з якими прагне наша держава. Але разом із тим очевидно, що рівень соціального забезпечення населення України є значно нижчим, аніж у європейських країнах. Тому в умовах потреби адаптації національного законодавства до законодавства Європейського Союзу, належного забезпечення прав людини, поваги до цінності їі життя і здоров'я, а також соціально-економічного забезпечення на рівні європейських стандартів важливо здійснити аналіз національних особливостей соціального законодавства різних європейських держав, а Франція у цьому контексті є одним із найвдаліших прикладів.

Питання, пов'язані із дослідженням законодавства Франції у різних сферах, регулярно досліджуються у працях вітчизняних науковців. Прикладами таких праць, близьких до тематики нашого дослідження, є роботи таких науковців, як: А.О. Більцан «Розвиток соціального захисту населення: історична довідка» [1], О.В. Борисюк «Імплементація зарубіжних моделей соціального страхування до вітчизняних реалій» [2], Г.В. Григораш, Т.Ф. Григораш, В.Я. Олійник, І.Т. Субачов «Системи соціального страхування зарубіжних країн» [3], О.I. Грициняк «До питання аналізу зарубіжного досвіду соціального забезпечення та можливості його впливу на відтворення робочої сили в Україні» [4], М.М. Любецька «Аналіз зарубіжного досвіду надання соціальних послуг, здійснення соціального супроводу сімей (осіб), які перебувають у складних життєвих обставинах» [7], Л.О. Нікілєва «Порівняльна характеристика фінансових моделей соціального забезпечення та захисту населення в "країні і світі» [8], О.В. Романець «Система соціального захисту: досвід Франції [23], Т.В. Салькова «Досвід державного управління системою пенсійного забезпечення (на прикладі Франції)» [24], О.В. Тищенко 
«Досвід соціального забезпечення населення в провідних країнах Свропейського Союзу» [26], O.В. Чернявська «Класифікація національних моделей пенсійного забезпечення; зарубіжний досвід та вітчизняна практика» [27], Є.П. Яригіна «Соціальне забезпечення сімей 3 дітьми: міжнародний досвід та українська модель» [28], Л.В. Ярова «Французький та британський досвід систем соціального захисту» [29] тощо. Разом із тим більшість 3 них мають загальний та переважно інформативний характер і не містять конкретних пропозицій для удосконалення законодавства України шляхом запозичення досвіду цієї держави. Тому проведення відповідних досліджень не втрачає доцільності.

Мета дослідження - аналіз соціального законодавства Франції, визначення його позитивних і негативних аспектів; співвідношення із соціальним законодавством України; виділення напрямів запозичення та формулювання пропозицій удосконалення законодавства України.

Французька модель соціального забезпечення населення заслужено вважається однією з найдревніших серед тих, що функціонують нині. Вона розпочала свій розвиток у середині XVIII ст., коли почало набувати поширення добровільне страхування робочих та їхніх родин. Оскільки добровільне страхування переважно лягало на плечі робітників і обтяжувало їхній бюджет, то воно було доступне лише забезпеченим верствам населення. У зв'язку з цим виникла необхідність організації нової форми соціального страхування - у вигляді обов'язкового страхування, завданням якого було усунення недоліків добровільного страхування, зокрема обмеженості поширення і малої інтенсивності наданої допомоги [1, с. 10]. У цьому аспекті Франція була однією з перших держав, у якій соціальне забезпечення зародилось у формах, в яких воно функціонує нині.

Натепер у світі є декілька моделей соціального захисту. Францію прийнято відносити до змішаної, адже вона займає проміжне становище між двома концептуальними моделями, сформованими західним суспільством. Французька модель дістала назву консервативно-корпоративістської, або франко-німецької, і фактично являє собою поєднання двох інших моделей - беверіджиської та бісмаркської [4, с. 97]. Перша, беверіджиська модель, передбачає державний перерозподіл доходів від більш багатих до бідних прошарків суспільства шляхом стягування податків і проведення цільових державних програм. Таким чином, державна соціальна політика охоплює все суспільство і має метою боротьбу з бідністю [23, с. 409]. Актуальність їі положень для Франції варто пов'язати 3 тим, що французький уряд перебував у Великобританії під час Другої світової війни. Під впливом доповіді У. Беверіджа було опубліковано Устав На- ціональної ради Опору (Charte du Conseil National de la Resistance, 1944), який закликав до організації «системи повного соціального забезпечення, покликаної гарантувати всім громадянам засоби для підтримки існування 3 моменту втрати ними можливості добувати їх своєю працею... » [1, с. 12]. Як наслідок, доповідь У. Беверіджа була використана у післявоєнні роки під час формування соціальної політики урядами багатьох європейських держав, у тому числі і Франції. Друга, бісмаркська модель, передбачає фінансування соціальних програм шляхом особливих відрахувань працюючих членів суспільства і поширюється виключно на них. Її мета - подолання матеріальних та соціальних труднощів працюючих. Першу модель можна охарактеризувати як ліберально-солідарну, другу - як консервативно-корпоративну.

3 часу виникнення французька система соціального захисту визначила свою мету виходячи 3 «беверіджиської» концепції, а засоби їі досягення мали «бісмаркський» характер [23, с. 409]. Ця модель поширилась на Францію, оскільки більшість дослідників пов'язують виникнення повноцінної системи обов' язкового державного соціального страхування в другій половині XIX ст. 3 діяльністю німецького канцлера Отто фон Бісмарка та прийняттям у Німеччині законів щодо соціального страхування населення. Основними ідеями моделі Бісмарка були такі: соціальне забезпечення базувалося виключно на праці, а тому обмежувалось лише особами, які зуміли заслужити право на соціальне забезпечення своєю працею; обов' язкове соціальне забезпечення було передбачене лише для тих найманих працівників, заробітна плата яких є нижчою за визначену мінімальну суму, тобто для тих, хто не може користуватися індивідуальним страхуванням; соціальне забезпечення було побудоване на методології страхування, що встановлює паритетне співвідношення між внесками найманих працівників та працедавців, а також між виплатами й внесками; соціальним забезпеченням управляють самі працедавці та наймані працівники; соціальне страхування було обов'язкове для всіх працюючих осіб [1, с. 11-12]. Тобто специфіка французької моделі соціального забезпечення населення полягає у тому, що в ньому одночасно беруть участь i державний, і недержавний сектори економіки. 3 одного боку, мають місце високі видатки на соціальні програми, що перевищують середній рівень по Європейському Союзу. Так, із 1970 до 2003 року видатки на соціальний захист у Франції зросли з 17,5 до $30,9 \%$ [8, с. 78]. 3 іншого боку, суттєвий внесок для функціонування такої системи здійснюють працюючі особи, які одночасно фінансують соціальні програми, які поширюються на всіх громадян, а також фінансують ті програми, які спрямовуються виключно на них. 
У середині минулого століття система соціального забезпечення Франції пережила суттєве реформування. Поступово заходів, що здійснювались державою, ставало не досить. Позначились темпи розвитку світової економіки, зростали вимоги до кваліфікації найманої праці, і відповідно, зростав рівень безробіття, не вистачало коштів, щоб забезпечувати всіх громадян, які цього потребували, а число осіб, охоплених різними соціальними допомогами, збільшувалось. Оскільки надходжень у бюджет, джерелом яких в основному є податок з доходів, було не досить, то у 1991 році був введений загальний соціальний внесок, а у 1996 році - внесок на погашення соціальної заборгованості. Завдяки цим заходам збільшився обсяг зборів з інших видів доходів [23, с. 410]. Як наслідок, було сформовано ту модель соціального забезпечення населення, яка натепер є зразком для багатьох країн світу.

Загалом, аналізуючи питання співвідношення українського соціального законодавства та соціального законодавства Франції, варто зазначити таке. Соціальне законодавство України натепер становлять Конституція України [5] та низка спеціальних законодавчих актів $[12 ; 13 ; 14 ; 15 ; 16 ; 17 ; 18 ; 19 ; 20 ; 21 ; 22]$. Втім, як демонструє приклад більш розвинених держав Європи, у тому числі й Франції, всі перераховані нормативно-правові акти замінює один спеціальний законодавчий акт або декілька таких актів. У Франції функціонує Кодекс соціального забезпечення 1956 року, яким визначено, що соціальне забезпечення захищає працівників та членів їхніх сімей від будь-яких ризиків, які можуть позбавити їх можливості заробляти на життя. Кодексом закріплено такі види соціального страхування: страхування по хворобі, страхування від нещасних випадків на виробництві та професійних захворювань, страхування по старості, страхування на випадок безробіття, сімейне страхування тощо. Втім, Кодекс соціального забезпечення не є єдиним кодифікованим нормативно-правовим актом у досліджуваній галузі суспільних відносин. Так, I.В. Новосельська відзначає, що, окрім Кодексу соціального забезпечення, також Кодекс взаємного страхування 2000 року містить норми, що регулюють соціальне забезпечення населення. Окремі положення про соціальне забезпечення містяться у Трудовому кодексі, Кодексі цивільних і військових пенсій державної служби тощо [9, с. 44]. Тобто соціальне законодавства Франції натепер становить значно менша кількість нормативно-правових актів. При цьому більшість норм соціального законодавства закріплені у рамках одного нормативно-правового акта - Кодексу соціального забезпечення. Звернемо увагу на те, що в Україні мали місце неодноразові спроби прийняти аналогічний нормативно-правовий акт. Наприклад, у 2012 році ініціатором такого законопроекту виступив народний депутат А.В. Яценко [25]. Втім, проект згодом було відкликано. I як наслідок, нині в Україні функціонує механізм, врегульований значно більшим числом нормативно-правових актів порівняно з європейськими державами, та Францією у тому числі.

Тож, зробимо висновок про те, що ще одним напрямом запозичення досвіду Франції є прийняття Соціального кодексу України. Із прийняттям такого нормативно-правового акта кожна особа матиме змогу знайти в одному акті (Соціальному кодексі України) захист прав і свобод, а його структуру доцільно сформулювати на основі міжнародних норм, визначених Європейською соціальною хартією, Європейським кодексом соціального забезпечення, практикою європейських країн, зокрема Франціі.

У Франції соціальні послуги здійснюються за різними напрямами діяльності з метою допомоги адресним групам відповідно до стандартів життя. Надання соціальних послуг здійснюється через комплексну структуру державного забезпечення 3 великою чисельністю децентралізованих послуг регіональної та окружної влади й соціальних і соціально-медичних установ. Як витікає з аналізу наукової літератури, система соціального забезпечення громадян у Франції включає: 1) пенсійне забезпечення; 2) медичне забезпечення; 3) систему підтримки сім'ї; 4) допомогу по безробіттю.

Пенсійне забезпечення. Державна пенсійна система по старості, яка охоплює основну масу пенсіонерів, являє собою складне багатоярусне утворення. Починаючи із 90 -х років і дотепер у країні діє близько 100 базових та понад 300 додаткових режимів пенсійного забезпечення. Пенсійна система складається 3 п'яти підсистем: базові режими для найманих працівників, додаткові режими, спеціальні режими для окремих категорій зайнятих, базові режими для ненайманих працівників, додаткові (факультативні) режими [24, с. 105]. Кожна з них має свою специфіку, що проявляється у фінансуванні, віці виходу на пенсію, тривалості страхового стажу для отримання повної пенсії, а також методиці вирахування розміру пенсіі. У цьому аспекті пенсійна система Франції відрізняється від української, у якій передбачено трудові пенсії, пенсії за віком, по інвалідності, в разі втрати годувальника, за вислугу років [21]. Також пенсійна система України складається із трьох підсистем - солідарної, накопичувальної та системи недержавного пенсійного забезпечення [16].

Фінансування базового режиму здійснюється в основному за рахунок соціальних внесків підприємців $(8,2 \%$ фонду заробітної плати) і найманих працівників (7,6\% від зарплати) [23, с. 410]. Окрім основних базових режимів, діють обов'язкові додаткові режими страхування, які об'єднують 
різні професійні категорії працюючих. Частину коштів становлять відсотки від розміщення вільних фінансових ресурсів, яке здійснюеться Центральним агентством установ соціального страхування. Пенсії колишніх працівників залежать від відрахувань нинішніх робітників, тобто тих, хто працює сьогодні та отримує зарплату в тій же компанії, галузі чи країні загалом. При цьому варто звернути увагу на те, що суттєвою особливістю пенсійної системи Франції залишається висока норма заміщення, тобто великий розмір пенсії порівняно з попередньою зарплатнею. Розмір пенсій становить $78 \%$ для чоловіків та $72 \%$ для жінок від суми попередньої заробітної плати [24, с. 108]. Як наслідок, такий рівень пенсій дає змогу населенню Франції зберігати фактично той самий piвень життя і після виходу на пенсію.

Звернемо увагу на те, що це стало можливим завдяки підвищенню пенсійного віку, внаслідок змін до пенсійного законодавства у жовтні 2010 року. Раніше французи виходили на пенсію в 60 років, якщо вони платили пенсійні відрахування протягом 40,5 року, і в 65 років, якщо платили відрахування менше цього періоду, після підвищення - в 62 і 67 років. Окрім того, необхідний термін виплати відрахувань до 2018 р. становитиме 42 роки, і при цьому вік виходу на пенсію чоловіків і жінок однаковий [24, с. 105]. Варто зазначити, що для України натепер підвищення пенсійного віку не $є$ доречним з огляду на вищий рівень смертності. Наприклад, із 100 тис. осіб віком 20-64 роки у 2013 році не доживали до 65 років $39,7 \%$ чоловіків в Україні [6, с. 57]. Ці дані свідчать про те, що навіть за нинішнього пенсійного віку значна частина громадян не доживає до його настання. Збільшивши пенсійний вік на основі французького досвіду до 62 і 67 років, частка громадян, які доживатимуть до пенсії, зменшиться ще суттєвіше.

Отже, пенсійна система Франції характеризується такими особливостями: 1) складність системи пенсійного забезпечення, яку становлять 100 базових та понад 300 додаткових режимів, а також п'яти підсистем; 2) пенсії колишніх працівників залежать від відрахувань нинішніх робітників, тобто тих, хто працює сьогодні та отримує зарплату в тій же компанії, галузі чи країні; 3) великий розмір пенсії порівняно з попередньою зарплатнею; 4) високий пенсійний вік.

Медичне забезпечення. У Франції діє ефективна система медичного страхування, яка охоплюе $80 \%$ населення країни. Фінансування системи охорони здоров'я у Франції здійснюється в основному за рахунок трьох джерел фінансування: загального бюджету, обов'язкового медичного страхування (основне джерело фінансування), особистих коштів громадян [3, с. 119]. Провідну роль відіграє обов'язкове медичне страхуван- ня, в рамках якого працівники та підприємства в обов'язковому порядку регулярно сплачують внески до страхової каси. Як наслідок, усі жителі Франції, навіть бідні та бездомні, мають право на страховий мінімум медичних послуг.

Медичне страхування є обов'язковим і оплачується працівником $(1 / 4)$ і роботодавцем $(3 / 4)$. Кожна особа у Франції, що має роботу, зобов'язана відраховувати кошти в національну систему соціального забезпечення, і без будь-якого винятку будь-яка особа - француз чи іноземець, працюючий і безробітний - має право на користування її благами. У разі серйозної і тривалої хвороби, а також у разі хвороб, що потребують дорогого лікування і хірургічного втручання, страхування ризику повне, тобто хворим витрати відшкодовуються повністю. Страховка виплачується частково у разі нескладних захворювань або так званих витрат по комфорту [23, с. 411]. Здійснюється обов'язкове страхування навіть студентів та школярів.

Із 1998 року фінансування охорони здоров'я здійснюється не тільки шляхом утримань із фонду заробітної плати найманих працівників на підприємствах, але і за рахунок податку на сукупний дохід через введення єдиного соціального внеску. Цей спосіб реформування зменшує пряму негативну дію на економічну активність, але оскільки безпосередньо відображається на сімейному доході, $\mathrm{i}$, як наслідок, на купівельній здатності населення. Національне зібрання щорічно затверджує єдиний «державний цільовий показник у галузі медичного страхування», тобто загальну межу витрат на медичне страхування. У відповідності до його рішень державні органи укладають угоди з касами соціального забезпечення, і зокрема, з Національною касою страхування по хворобах. Каса, своєю чергою, укладає угоди з лікарями та іншими співробітниками системи охорони здоров'я [23, с. 411-412]. Як наслідок, система функціонує таким чином: пацієнт, попередньо записавшись на прийом до лікаря, платить йому за візит і за всі види медичних послуг: аналізи, консультації тощо. Лікар заповнює спеціальний лист, на основі якого пацієнт отримує в касі страхування повну або часткову компенсацію. Безкоштовні медичні послуги надаються інвалідам та важкохворим, які не мають коштів на лікування [3, с. 119]. За умов стандартних розцінок компенсується $80 \%$ вартості лікування та від 80 до $40 \%$ вартості ліків залежно від ступеня їх медичної необхідності. Необов'язкові ліки не оплачуються. Звичайна вартість візиту до лікаря становить 20 євро, але може бути вищою залежно від кваліфікації лікаря. У разі важкого захворювання, включно з хворобами, пов'язаними зі старістю, страхування покриває $100 \%$ вартості лікування та ліків. «Carte vitale» слугує грошовим еквівалентом. Ліки, які виписуються лікарем, можна без проблем купити в будь-якій французькій аптеці. 
Управління системою медичного страхування здійснюється за принципом паритету: кожне регіональне відділення ( «каса») має свою керівну раду, що складається 3 представників профспілок та спілок працедавців у співвідношенні 50/50. У разі суперечностей держава виступає арбітром. Приватні внески пацієнтів дуже обмежені, фінансування має переважно суспільний характер [23, с. 412-413].

Окрім страхових кас, у Франції є численні товариства взаємодопомоги, які здійснюють додаткові види страхування, наприклад, оплату медикаментозної та стоматологічної допомоги. Такі товариства беруть участь у сплаті рахунків своїх членів первинним страховим касам або пропонують своїм членам допомогу щодо догляду за людьми похилого віку. Діяльність товариств взаємодопомоги координується національною федерацією. Крім того, Франція має розгалужену сітку приватних страхових компаній [3, с. 120]. Це дає змогу зробити висновок про те, що у Франції обов'язкове і добровільне медичне страхування розвиваються паралельно.

Таким чином, система медичного забезпечення, сформована у Франції, характеризується такими особливостями: 1) обов'язковість медичного страхування; 2) фінансування охорони здоров'я здійснюється шляхом утримань із фонду заробітної плати найманих працівників на підприємствах та за рахунок податку на сукупний дохід через введення єдиного соціального внеску; 3) високий рівень компенсацій; 4) паралельний розвиток обов'язкового і добровільного медичного страхування.

Систела підтрилки сіл'ї. Важливим складником системи соціального забезпечення Франції є система підтримки сім'ї. Фінансування сімейних допомог здійснюється переважно за рахунок підприємств, внески яких починаючи з 1990 року розраховуються з усього фонду виплаченої заробітної плати. Ці внески, а також частка держави перерозподіляються Національною касою сімейних допомог, а також допомог цільового характеру, наприклад, на оплату житла і працевлаштування. Система підтримки сім'ї гарантує фінансову допомогу всім французьким сім'ям незалежно від доходів, а також додаткові послуги, наприклад, оплату дитсадків (відповідно до доходів). Сім'я, що очікує дитину, отримує близько 2 тисяч євро, які виплачуються в три етапи (перші дві виплати до обов'язкового відвідування жінкою лікаря, третя до народження дитини). Надалі і до досягнення дитиною 20 років сім'я отримує на неї щомісячну допомогу (близько 100 євро на кожного з двох і більше дітей) [23, с. 413].

Отже, зробимо висновок, що система підтримки сім’ї у Франції має такі особливості: 1) фінансування сімейних здійснюється переважно за рахунок внесків 3 фонду виплаченої заробітної плати підприємств; 2) здійснюється у формі допомог цільового характеру, наприклад, на оплату житла і працевлаштування, оплату дитсадків і канікулярних центрів; 3) високий рівень допомоги, що значно вищий, ніж в Україні.

Допологи по безробіттю. У Франції більш високий, ніж у середньому по Євросоюзу, рівень безробіття, що коливається в межах від 8,5 до $12 \%$. Це найбільш болюча проблема для французького суспільства, бо вона торкається тих, хто взагалі не має роботи, і тих, хто працює за трудовим контрактом 3 визначеним терміном. 3 метою створення робочих місць 3 початку 70-х років стали здійснюватися заходи економічного і соціального характеру щодо скорочення безробіття. Перші з них були спрямовані на збереження підприємствами чисельності персоналу або залучення нових працівників. Держава бере на себе (повністю або частково) відрахування внесків у фонди соціального забезпечення тих підприємств, які зобов'язуються створити робочі місця. Заходи соціального характеру полягали у варіюванні умов і тривалості праці, поширенням дострокового виходу на пенсію в галузях, що переживали кризу. Окрім того, поширення набула практика роботи на півставки чи часткова зайнятість, а також оплата навчання і перекваліфікації безробітних [23, с. 413-414].

Допомоги по безробіттю виплачуються особам, які втратили роботу через Національний міжпрофесійний торгово-промисловий центр зайнятості (ЮНЕДІК). Є категорія безробітних, що не мають права на пряму матеріальну допомогу, оскільки вони не працювали і не робили відрахувань у страхові фонди. Щодо таких осіб застосовуються виплата допомоги на працевлаштування, призначеної для сприяння в пошуках роботи чи повернення до неї, що надає їй новаторський соціальний характер. Допомога фінансується переважно державою і розподіляється через каси сімейних допомог. Боротьба проти бідності стала загальнонаціональним завданням і об'єднала широкі верстви населення навколо представників спеціалізованих закладів і державних органів, які впроваджують у життя масштабну програму, спрямовану на забезпечення кожному доступу до основних прав (зайнятість, житло, охорона здоров'я, освіта, культура) і запобігання ситуаціям, що призводять до виключення із суспільного життя [23, с. 414].

Отже, французька система допомоги по безробіттю має такі особливості: 1) передбачає допомоги по безробіттю для тих осіб, які втратили роботу, та допомоги на працевлаштування для тих осіб, які не працювали і не робили відрахувань у страхові фонди; 2) цей вид допомоги фінансується переважно державою.

Таким чином, здійснене дослідження дає змогу зробити висновок про те, що до особливостей французької системи соціального забезпечення населення варто віднести такі: 
1. Розгалужену складну систему видів соціального страхування. Для порівняння в Україні передбачено декілька схем соціального страхування, наприклад, соціальне страхування на випадок безробіття, соціальне страхування з тимчасової втрати працездатності, соціальне страхування від нещасного випадку на виробництві та професійного захворювання, які спричинили втрату працездатності, пенсійне страхування. Тобто і французька, і українська модель є у схожій мірі різноплановими.

2. Розвинену систему сімейних виплат. В Україні Законом України «Про державну допомогу сім'ям з дітьми» від 21.11.1992 № 2811XII [12] передбачено такі види допомоги: допомога у зв'язку з вагітністю та пологами; допомога при народженні дитини; допомога при усиновленні дитини; допомога на дітей, над якими встановлено опіку чи піклування; допомога на дітей одиноким матерям; допомога на дітей, хворих на тяжкі захворювання тощо. Тобто в Україні також встановлено доволі масштабну систему сімейних виплат. Проте французька система суттєво відрізняється від української та від будь-якої іншої моделі соціальної допомоги сім'ям. Так, фінансування допомоги сім'ям здійснюється переважно за рахунок підприємств, внески яких починаючи з 1990 року розраховуються з усього фонду виплаченої заробітної плати. Ці внески, а також частка держави перерозподіляються Національною касою сімейних допомог, спеціально створеною для функціонування цього виду забезпечення. Система підтримки родини гарантує фінансову допомогу французьким родинам, незалежно від їхніх статків, а також додаткові послуги [23, с. 413]. Утім, головна особливість французької системи сімейних виплат все ж полягає у розмірах цих виплат.

3. Значну роль додаткових систем соціального захисту, особливо у сфері пенсійного й медичного страхування. Прикладами додаткових систем соціального захисту, які функціонують в Україні, є недержавні пенсійні фонди, а також накопичувальна система загальнообов'язкового державного пенсійного страхування. У Франції також функціонують подібні механізми, набула розвитку система медичного страхування. Звернемо увагу на те, що в Україні подібні додаткові системи лише запроваджуються. Наприклад, із прийняттям в Україні законів «Про загальнообов'язкове державне пенсійне страхування» від 09.07.2003 № 1058-IV [16] та «Про недержавне пенсійне забезпечення» від 09.07.2003 № 1057-IV [18] було передбачено встановлення трьохрівневої пенсійної системи в Україні. Однією із цих підсистем визначено накопичувальну систему загальнообов'язкового державного пенсійного страхування. Під час прийняття цих нормативно-правових актів передбачалось, що накопичувальна система загаль- нообов'язкового державного пенсійного страхування буде введена в дію у 2012 році, а її сутність полягатиме у спрямуванні частини обов'язкових пенсійних відрахувань на персональні рахунки громадян. Ці кошти будуть інвестуватися в українську економіку, а інвестиційний дохід збільшуватиме розмір майбутніх пенсійних виплат. Проте запрацювала вона лише з початку 2019 року, згідно з набуттям чинності Закону України «Про внесення змін до деяких законодавчих актів України щодо підвищення пенсій” від 03.10.2017 № 2148VIII [11]. Щодо недержавних пенсійних фондів вони в Україні функціонують порівняно давно, проте не набули поширення. Як свідчить статистика, станом на 31.12.2017 року в Державному реєстрі фінансових установ містилася інформація про 64 недержавні пенсійні фонди. Кількість осіб, задіяних у системі недержавного пенсійного страхування, станом на 31.12.2017 року становила 840,8 тисячі осіб [10, с. 1-2]. Тобто, незважаючи на доволі тривалий період існування недержавного пенсійного забезпечення, ним охоплена незначна частина населення України. Тому доречним буде висновок, що розвиток додаткових систем соціального захисту населення в Україні є значно нижчим, аніж у Франції, але натепер наша держава розвивається в цьому напрямі.

4. Управління соціальним захистом у Франції організовано ієрархічно у вигляді діючих на національному й регіональному рівнях страхових кас, відповідальних за конкретний вид соціального захисту. В Україні згідно з нормами Закону «Про загальнообов'язкове державне соціальне страхування» від 23.09.1999 № 1105-XIV [17] органом, який здійснює керівництво та управління загальнообов'язковим державним соціальним страхуванням, є Фонд соціального страхування України, та який $є$ аналогом страхових кас, які функціонують у Франції. На місцевому рівні діють відділення виконавчої дирекції Фонду соціального страхування України. Проте французькі страхові каси відрізняються від Фонду соціального страхування, передусім у контексті управління ними. Так, і Фонд, і страхові каси є самоврядними організаціями, проте якщо управління страховими касами здійснюється представниками застрахованих і роботодавців, то управління Фондом здійснюється, окрім представників застрахованих осіб та роботодавців, ще й державою. Тобто самоврядність та автономність цього органу в Україні є обмеженою, адже у його управлінні задіяний державний елемент.

5. Систематизація соціального законодавства, зокрема прийняття Кодексу соціального забезпечення. В Україні порівняно з Францією діє значно масштабніша система соціального законодавства. Як наслідок, пересічному громадянину проблематично розібратись у тих можливостях, які йому надаються державою. Тому у цьому аспекті 
вважаємо французьке соціальне законодавство досконалішим за українське.

6. Високий рівень фінансування соціальної допомоги, який є одним із найвищих у Європі, при чому за рахунок переважно внесків соціального страхування. По суті, залучення коштів до системи соціального забезпечення в Франції здійснюється у той самий спосіб, що і в Україні, а відповідні каси є аналогами тих фондів, які функціонують у нашій державі. Втім, враховуючи рівень економічного розвитку Франції, рівень заробітних плат, відсутність тіньових заробітних плат, кошти, які перерозподіляються на соціальні потреби, у Франції є значно більшими. Тому зробимо висновок, що досягнення такого рівня соціального забезпечення населення, який є притаманним для Франції, насамперед потребує створення таких економічних можливостей, які є у цій державі.

Проаналізувавши такі загальні особливості системи соціального забезпечення громадян у Франції, зробимо висновок, що Україні насамперед варто розвивати додаткові системи соціального захисту, особливо у сфері пенсійного й медичного страхування (зокрема, накопичувальну систему загальнообов'язкового державного пенсійного страхування та недержавне пенсійне страхування, а також звернути увагу на досвід Франції у сфері медичного страхування). Це дасть змогу збільшити розмір пенсійного забезпечення населення, а також зменшити бюджетне навантаження, адже натепер дефіцит Пенсійного фонду України компенсується за рахунок коштів Державного бюджету України.

Загалом, аналіз специфіки соціального забезпечення населення у Франції продемонстрував, що Франція справді є соціальною державою не лише декларативно, але й по факту. Питанням, присвяченим соціальній допомозі населення, присвячується серйозна увага з боку французького законодавця. Порівнюючи систему соціального забезпечення України та Франції, не можна зробити однозначний висновок про те, що українська модель гірша. В Україні так само функціонує масштабна система пенсійного забезпечення, яка дає можливість суттєво збільшувати розмір пенсійного забезпечення, що надається державою. Так само в Україні велика увага приділяється захисту сім’ї та боротьбі з бідністю й безробіттям. Але у Франції функціонують такі фінансові механізми, які надають можливість залучати у систему соціального забезпечення суттєві кошти за рахунок внесків на соціальне страхування. В Україні натепер такі можливості є, проте з огляду на низький розмір заробітних плат та наявність тіньового ринку праці залучення такого обсягу коштів у систему соціального забезпечення нині неможливе. Тому насамперед для нашої держави важливо проаналізувати та застосувати досвід побудови різноманітних економічних механізмів, які є характерними для Франції.

Також, на нашу думку, досвід формування моделі соціального забезпечення Франції є корисним для України в таких напрямах:

1) розвиток додаткових систем соціального захисту, особливо у сфері пенсійного й медичного страхування (зокрема, накопичувальну систему загальнообов' язкового державного пенсійного страхування, недержавне пенсійне страхування та медичне страхування);

2) прийняття Соціального кодексу України.

Звернемо увагу на те, що розвиток додаткових систем соціального захисту в Україні вже відбувається. Проте натепер пройшло занадто мало часу для того, щоб робити висновки щодо ефективності накопичувальної системи загальнообов'язкового державного пенсійного страхування, недержавного пенсійного страхування та медичного страхування. Втім, усе ж звернемо увагу на незначний рівень залучення громадян до таких систем. Щодо питання прийняття Соціального кодексу України, то воно періодично порушується, нині є відповідні законопроєкти, тож можна зробити висновок, що рано чи пізно це питання буде вирішене. А тому завдання вітчизняних науковців - продовжувати дослідження позитивного досвіду більш розвинених держав, у тому числі й Франції.

\section{Jimepamypa}

1. Більцан А.О. Розвиток соціального захисту населення: історична довідка. Держава та регіони. Сер. : Економіка та підприємниитво. 2013. № 2. С. 9-14.

2. Борисюк О.В. Імплементація зарубіжних моделей соціального страхування до вітчизняних реалій. Молодий вчений. 2017. № 4. С. 5-8.

3. Григораш Г.В., Григораш Т.Ф., Олійник В.Я., Субачов I.T. Системи соціального страхування зарубіжних країн : навчальний посібник. Дніпропетровськ : ДДФА, 2007. $146 \mathrm{c.}$

4. Грициняк O.I. До питання аналізу зарубіжного досвіду соціального забезпечення та можливості його впливу на відтворення робочої сили в Україні. Науковий вісник Ужгородського національного університету : Серія: Міжнародні економічні відносини та світове господарство / голов. ред. М.М. Палінчак. Ужгород : Видавничий дім «Гельветика», 2016. Вип. 7. Ч. 1. С. 96-99.

5. Конституція України : Закон України від 28.06.1996 р. № 254к/96-ВР. Відолості Верховної Ради Украӥни (ВВР). 1996 р. № 30. Ст. 141.

6. Левчук Н.М. Здоров'я і тривалість життя в Україні у контексті формування передумов інноваційної зайнятості. Делографія та соиіальна еконоліка. 2017. № 1. С. 54-65.

7. Любецька М.М. Аналіз зарубіжного досвіду надання соціальних послуг, здійснення соціального супроводу сімей (осіб), які перебувають у складних життєвих обставинах. Інвестииї: практика та досвід. Київ, 2018. № 19. С. 109-116.

8. Нікілєва Л.О. Порівняльна характеристика фінансових моделей соціального забезпечення та захисту населення в Україні та світі. Науковий вісник Полтавського університету економіки і торгівлі. Серія : Економічні науки. 2011. № 3. С. 76-82. 
9. Новосельська I. Кодифікація законодавства України із соціального забезпечення / I. Новосельська, М. Руше. Підприємниитво, господарство і право. 2017. № 7. C. 43-45.

10. Підсумки розвитку системи недержавного пенсійного забезпечення станом на 31.12.2017. URL: https://www.nfp.gov.ua/files/17_Dep_Repetska/NPF IV $\mathrm{kv} \%$ 202017.pdf.

11. Про внесення змін до деяких законодавчих актів України щодо підвищення пенсій : Закон України від 03.10.2017 № 2148-VIII. Відомості Верховної Ради $(B B P)$. 2017. № 40-41. Ст. 383.

12. Про державну допомогу сім'ям з дітьми : Закон України від 21.11.1992 № 2811-XII. Відомості Верховної Ради України від 02.02.1993. № 5. Стаття 21.

13. Про державну соціальну допомогу малозабезпеченим сім'ям : Закон України від 01.06.2000 № 1768 III. Відомості Верховної Ради України від 01.09.2000. № 35. Стаття 290 .

14. Про державну соціальну допомогу особам з інвалідністю $з$ дитинства та дітям з інвалідністю : Закон України від 16.11.2000 № 2109-III. Відомості Верховної Ради України від 05.01.2001. № 1. Стаття 2.

15. Про державну соціальну допомогу особам, які не мають права на пенсію, та особам з інвалідністю : Закон України від 18.05.2004 № 1727-IV. Відомості Верховної Ради України від 20.08.2004. № 33-34. С. 1354. Стаття 404.

16. Про загальнообов'язкове державне пенсійне страхування : Закон України від 09.07.2003 № 1058IV. Відомості Верховної Ради Украӥни від 12.12.2003. № 49. Стаття 376 .

17. Про загальнообов'язкове державне соціальне страхування : Закон України від 23.09.1999 № 1105 XIV. Відомості Верховної Ради України. 1999. № 46-47. Ст. 403.

18. Про недержавне пенсійне забезпечення : Закон України від 09.07.2003 № 1057-IV. Відолості Верхов ної Ради Украйни від 28.11.2003. № 47. Стаття 372 .

19. Про основи соціальної захищеності осіб з інвалідністю в Україні : Закон України від 21.03.1991 № 875-XII. Відомості Верховної Ради УРСР від 21.05.1991. № 21. Стаття 252 .

20. Про основні засади соціального захисту ветеранів праці та інших громадян похилого віку в Україні : Закон України від 16.12.1993 № 3721-XII. Відомості Верховної Ради України від 25.01.1994. № 4. Стаття 18.

21. Про пенсійне забезпечення : Закон України від 05.11.1991 № 1788-XII. Відолості Верховної Ради України від 21.01.1992. № 3. Стаття 10 .

22. Про статус ветеранів війни, гарантії їх соціального захисту : Закон України від 22.10.1993 № 3551XII. Відомості Верховної Ради України від 09.11.1993. № 45 . Стаття 425 .

23. Романець О.В. Система соціального захисту: досвід Франції. Наукові записки Національного університету «Острозька академія». Серія: Еконоліка. 2012. Вип. 10. Ч. 2. С. 408-416.

24. Салькова Т.В. Досвід державного управління системою пенсійного забезпечення (на прикладі Франції). Ефективність державного управління : зб. наук. пр. Львівського регіонального інституту державного управління Національної академії державного управління при Президентові України. Вип. 1 (50) : у 2 ч. / за заг. ред. чл.-кор. НАН України В.С. Загорського, доц. А.В. Ліпенцева. Львів : ЛРІДУ НАДУ, 2017. С. 103-109.

25. Соціальний кодекс України : проєкт Закону України № 11061 від 02.08.2012. URL: http://w1.c1.rada.gov.ua/pls/zweb2/webproc4 1?id= $\& \mathrm{pf} 3511=44133$.
26. Тищенко О.В. Досвід соціального забезпечення населення в провідних країнах Європейського Союзу. Науковий вісник Херсонського державного університе ту. Серія : Юридичні науки. 2015. Вип. 2 (2). С. 76-81.

27. Чернявська О.В. Класифікація національних моделей пенсійного забезпечення; зарубіжний досвід та вітчизняна практика / О.В. Чернявська, О.А. Горбунова. Економіка та держава. 2013. № 2. С. 38-44.

28. Яригіна Є.П. Соціальне забезпечення сімей 3 дітьми: міжнародний досвід та українська модель : монографія. Харків : Монолит, 2016. 196 с.

29. Ярова Л.В. Французький та британський досвід систем соціального захисту. Наукові праці Чорноморського державного університету ілені Петра Могили. Сер. : Політологіл. 2011. Т. 175, Вип. 163. С. 118-121.

\section{Анотація}

Малюга Л. Ю. Соціальне забезпечення населення у Франції: зміст та шляхи вдосконалення соціального законодавства України. - Стаття.

Євроінтеграційні процеси в Україні зумовили актуалізацію питань, пов'язаних з удосконаленням вітчизняного законодавства та приведенням його у відповідність до стандартів, характерних для провідних європейських держав. Однією з таких держав є Франція, чий досвід законотворення традиційно досліджується вітчизняними науковцями.

Соціальна сфера в Україні традиційно визнається однією з найпроблемніших. Формування високоякісного та ефективного соціального законодавства натепер $є$ однією з головних задач, поставлених перед державою, i одним із можливих напрямів його удосконалення $\epsilon$ використання позитивного досвіду більш розвинених держав. У Франції сфера соціального забезпечення перебуває на якісно вищому рівні порівняно з Україною, що підтверджується наявністю відповідних досліджень. Вітчизняні науковці часто звертаються до аналізу особливостей соціального законодавства Франції, втім переважно без формулювання пропозицій удосконалення соціального законодавства України. Франція характеризується високими соціальними стандартами та багатовіковим досвідом законотворення, а отже, для України важливо спиратись на досвід таких країн.

Мета цієї статті - здійснити аналіз соціального законодавства Франції, визначити його позитивні і негативні аспекти, порівняти соціальне законодавство Франції із соціальним законодавством України, виділити напрями запозичення позитивного досвіду та сформулювати пропозиції щодо удосконалення соціального законодавства України.

Під час дослідження нами встановлено, що система соціального забезпечення Франції є однією з найдосконаліших у Європі та є зразком для нашої держави. Ми дійшли висновку, що досвід соціального забезпечення у Франції є корисним для України в аспекті систематизації законодавства, а також розвитку додаткових систем соціального забезпечення.

Ключові слова: право на соціальний захист, соціальне законодавство, законодавство Франції, соціальне законодавство Франції, удосконалення соціального законодавства України.

\section{Summary}

Milyuga L. Yu. Social security of the population in France: the content and ways of improving the social legislation of Ukraine. - Article.

European integration processes in Ukraine have actualized issues related to the improvement of domestic legislation and bringing it in line with the typical standards 
of the leading European states. One such state is France, whose experience of lawmaking has traditionally been investigated by domestic scientists.

The social sphere in Ukraine is traditionally recognized as one of the most problematic. The formation of high-quality and effective social legislation is one of the main tasks set before the state, and one of the possible directions for its improvement is to use positive experience of more developed countries. In France the social welfare field is at a high level in comparison with Ukraine, which is confirmed by the availability of relevant research. Domestic scholars often turn to the analysis of the social legislation of France, however, without formulating proposals for improving the social legislation of Ukraine. France is characterized by high social standards and centuries-long experience of lawmaking, and therefore it is important for Ukraine to rely the experience of such countries.
The purpose of this article is to analyze the social legislation of France, to determine its positive and negative aspects, to compare the social legislation of France with the social legislation of Ukraine, to allocate directions of borrowing positive experience and to formulate proposals for the improvement of social legislation of Ukraine.

During the study, we found that France's social security system is one of the most advanced in Europe and is a model for our state. We came to the conclusion that the experience of social security in France is useful for Ukraine in the aspect of systematization of legislation, as well as the development of additional social security systems.

Key words: right to social protection, social legislation, legislation of France, social legislation of France, improvement of social legislation of Ukraine. 